\title{
PERANCANGAN APLIKASI REMINDER DAN MONITORING JADWAL SERVIS SEPEDA MOTOR BERBASIS ANDROID
}

\author{
Holis Muchlis Sugianto ${ }^{1}$, Asti Herliana² \\ ${ }^{1}$ Universitas Adhirajasa Reswara Sanjaya \\ e-mail: holissugiant42@gmail.com \\ ${ }^{2}$ Universitas Adhirajasa Reswara Sanjaya \\ e-mail: asti@ars.ac.id
}

\begin{abstract}
Abstrak
Sepeda motor merupakan alat transportasi yang banyak digunakan di Indonesia. Hal tersebut disebabkan karena kebutuhan masyarakat akan kendaraan yang dapat mendukung pola kehidupan yang sangat dinamis. Sehingga sebagian masyarakat lebih memilih menggunakan sepeda motor dibandingkan dengan kendaraan lain. Dengan pola kehidupan yang semakin dinamis, membuat mobilitas pengguna sepeda motor menjadi lebih tinggi. Hal tersebut diiringi dengan meningkatnya kecelakaan lalu lintas yang melibatkan sepeda motor. Banyak faktor yang menjadi penyebab terjadinya kecelakaan, salah satunya malfungsi pada sparepart sepeda motor. Malfungsi pada sparepart itu sendiri dapat disebabkan karena kelalaian dalam melakukan servis kendaraan secara rutin. Oleh karena itu, pada penelitian kali ini diusulkan sebuah aplikasi pengingat dan penjadwalan servis agar pengguna sepeda motor dapat membuat pengingat yang dapat digunakan untuk penjadwalan servis sehingga dapat menghindari keterlambatan dalam melakukan servis. Pada penelitian kali ini metode yang digunakan adalah metode kualitatif, sedangkan perancangan sistem pada aplikasi ini menggunakan bahasa pemrograman Java, $X M L$, dan SQLite sebagai database. Dengan adanya aplikasi reminder dan monitoring jadwal servis sepeda motor berbasis android ini diharapkan dapat membantu para pengguna sepeda motor dalam membuat pengingat servis secara rutin dan mengetahui kapan sebaiknya sepeda motor dapat diservis.
\end{abstract}

Kata Kunci: Reminder, Monitoring, Sepeda Motor, Servis, Android Mobile

\begin{abstract}
Motorcycle is a means of transportation that many used in Indonesia. It is caused because the public need for vehicles that can support life patterns very dynamic. So that some people prefer to use motorbikes compared to other vehicles. With an life pattern the more dynamic, making mobility motorcycle user becomes higher. It is accompanied with increasing traffic accidents involving a motorcycle. Many factors cause accidents, one of which is malfunction in motorcycle spare parts. Malfunctions in the spare parts themselves can be caused by negligence in routine vehicle servicing. Therefore, in this study a reminder and service scheduling application is proposed so that motorcycle users can create reminders that can be used for scheduling services so as to avoid delays in service. In this study the method used is a qualitative method, while the system design in this application uses programming language Java, XML, and SQLite as a database. With the application reminder and monitoring service schedule motorcycle for android based expected to help motorcycle users in making service reminders routinely and knowing when the motorcycle can be serviced.
\end{abstract}

Keywords: Reminder, Monitoring, Motorcycle, Service, Mobile Android 


\section{Pendahuluan}

Kendaraan bermotor khususnya sepeda motor merupakan alat transportasi yang banyak digunakan di Indonesia. Menurut data dari Badan Pusat Statistik (BPS), terlihat peningkatan pengguna sepeda motor dari tahun ke tahun. Setidaknya, pada tahun 2018 terdapat 120 juta pengguna sepeda motor di Indonesia (BPS, 2020). Peningkatan ini terjadi disebabkan karena kebutuhan masyarakat akan kendaraan yang dapat mendukung pola kehidupan yang sangat dinamis. Sehingga sebagian orang lebih memilih menggunakan sepeda motor dibandingkan dengan kendaraan lain, seperti mobil pribadi atau angkutan umum (Chairin, 2018). Dengan pola kehidupan yang semakin dinamis, membuat mobilitas pengguna sepeda motor menjadi lebih tinggi. Hal tersebut diiringi dengan meningkatnya kecelakaan lalu lintas yang melibatkan sepeda motor. Menurut data dari Korps Lalu Lintas Polri (Korlantas), pada 1 Januari - 15 April 2020 terdapat 96 kasus kecelakaan, angka ini menjadi yang tertinggi bila dibandingkan dengan jenis kendaraan lainnya (Korlantas, 2020).

Berdasarkan data dari Korlantas Polri, sepeda motor menjadi penyumbang terbanyak kasus kecelakaan pada awal tahun 2020. Hal tersebut dapat terjadi karena kelalaian pengendara ataupun kondisi sepeda motor yang kurang baik pada saat digunakan. Maka dari itu, melakukan pengecekan dan servis kendaraan secara rutin sangatlah penting. Keuntungan melakukan servis secara rutin adalah membuat sepeda motor menjadi aman, nyaman, mengurangi risiko kecelakaan pada saat digunakan di jalan raya, dan menghindari kerusakan berat pada mesin (Rohman, 2017). Dalam beberapa kasus, kerusakan pada sepeda motor disebabkan oleh kurangnya kesadaran untuk melakukan servis secara rutin. Masyarakat pada umumnya melakukan servis hanya pada saat kendaraan mereka mengalami kerusakan atau ketidak nyamanan pada saat digunakan. Pengetahuan waktu perawatan juga sangat penting agar dapat mengetahui kapan sebaiknya sepeda motor diberikan servis. Berdasarkan permasalahan yang terjadi, maka diusulkan sebuah aplikasi pengingat perawatan sepeda motor secara berkala.

Usulan solusi pada penelitian kali ini didasarkan pada penelitian sebelumnya yang dilakukan oleh Novi (2016). Pada penelitian ini didapatkan bahwa, menggunakan pengingat (reminder) dan pemberitahuan melalui notifikasi kepada pengguna sepeda motor tentang waktu servis dapat menghindari keterlambatan dalam melakukan servis, serta dapat mengecek data servis yang pernah dilakukan (Novi Airbat Lestiono et al., 2016). Menurut Ayuninghemi \& Abdillah (2018), pemakaian sepeda motor dengan mobilitas yang tinggi terkadang melupakan kondisi mesin yang seharusnya sudah di servis. Untuk menghindari hal tersebut, maka dibutuhkan suatu aplikasi atau alat yang dapat memberikan notifikasi servis kepada pengguna kendaraan (Ayuninghemi \& Abdillah, 2018). Sedangkan menurut Santana (2017), setiap kerusakan tidak selalu mengarah pada pemilik kendaraan, terkadang faktor ketidak sengajaan bisa terjadi, seperti lupa kapan kendaraan akan diservis (Santana et al., 2017).

Berdasarkan pemaparan latar belakang, permasalahan, dan solusi. Maka penelitian kali ini akan melakukan analisis mengenai pembuatan sebuah aplikasi sederhana berbasis android untuk sistem reminder dan monitoring jadwal servis sepeda motor yang ideal pada sepeda motor. Sistem ini merupakan suatu inovasi dalam membuat monitoring perawatan sepeda motor yang memanfaatkan perkembangan teknologi yang memiliki banyak manfaat bagi pengendara sepeda motor. Aplikasi smartphone yang dibuat diharapkan menguntungkan berbagai pihak seperti pengguna sepeda motor dan pemilik bengkel yang menjadi tempat servis sepeda motor.

\section{Metode Penelitian}

Metode penelitian yang digunakan pada penelitian kali ini adalah metode deskriptif dengan pendekatan kualitatif. Untuk menjabarkan kerangka berfikir yang dilakukan pada penelitian kali ini, maka dilakukan penjabaran penelitian melalui metodologi penelitian sebagai berikut : 


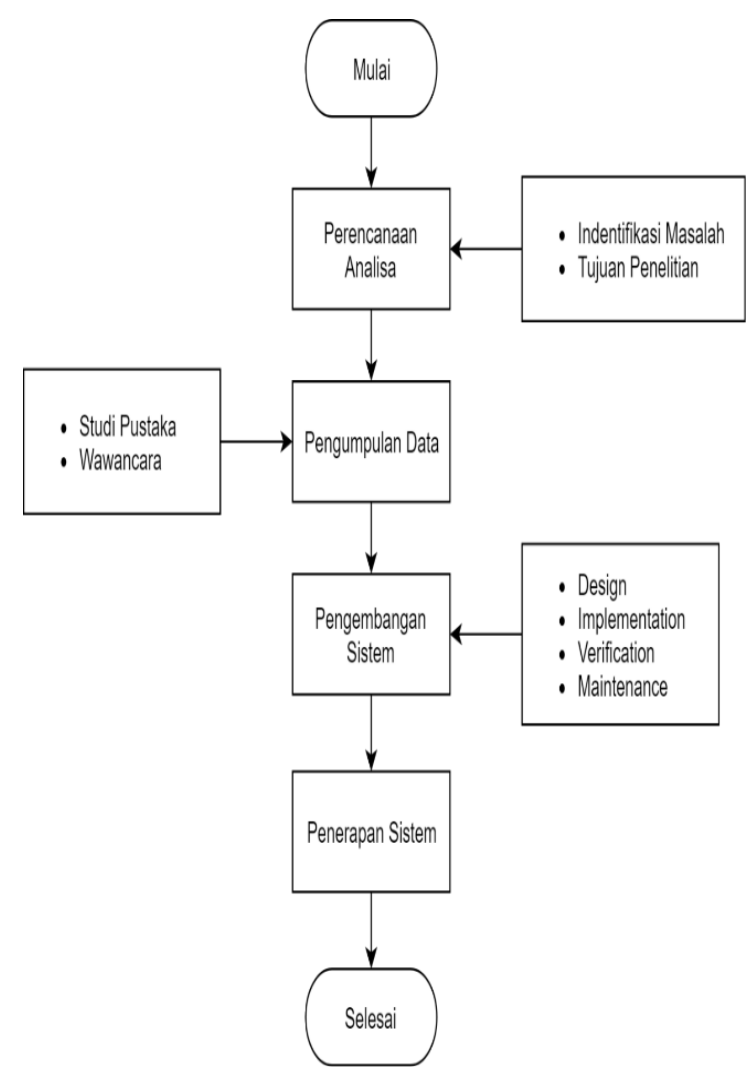

Gambar 1. Metodologi Penelitian

\subsection{Teknik Pengumpulan Data}

Pengumpulan data dilakukan dengan cara menggali informasi secara langsung melalui wawancara bersama narasumber. Narasumber yang dimaksud dalam penelitian ini yaitu mekanik sepeda motor dan pengguna sepeda motor sport, bebek (cub), dan matic. Selain itu, pengumpulan data juga dilakukan dengan cara mencari dokumen-dokumen yang akan menjadi bahan acuan dalam penelitian. Pada dasarnya tahapan ini bukan hanya sekedar kegiatan pengumpulan data, tetapi juga merupakan kegiatan pengelompokan data yang sudah tersedia sesuai dengan kategori tertentu sehingga dapat memudahkan pada proses selanjutnya.

\subsection{Model Pengembangan Aplikasi}

Metode pengembangan aplikasi yang digunakan adalah model waterfall. Model waterfall merupakan proses pengembangan sistem dimana antara satu fase ke fase yang lain dilakukan secara berurutan. Dalam proses implementasi model waterfall, sebuah langkah akan diselesaikan terlebih dahulu dimulai dari tahapan pertama sebelum melanjutkan ke tahap yang berikutnya. Setiap tahapan melewati fase Requirenments, Design, Implementation, Verification, dan Maintenance (Faisal, 2019).

1. Analisis kebutuhan sistem (Requirenments)

Tahap ini merupakan analisa kebutuhan sistem secara lengkap. Pengumpulan data bisa melakukan sebuah penelitian, wawancara, atau studi literatur. Peneliti harus mengerjakan fase ini secara lengkap untuk bisa menghasilkan desain yang lengkap. Pada tahap ini menganalisa kebutuhan-kebutuhan yang digunakan yaitu data jadwal servis sepeda motor dan kilometer maksimal servis.

2. Design

Design sistem pada penelitian ini digambarkan melalui model UML berupa use case diagram, activity diagram, dan sequence diagram. Design sistem di sini merupakan suatu proses yang bertujuan untuk mengubah kebutuhan-kebutuhan sistem menjadi sebuah bentuk cetak biru (blueprint) aplikasi. Sehingga hasil design dapat digunakan dalam proses pembangunan aplikasi.

3. Implementation

Tahap ini merupakan tahap dimana proses coding dilakukan yang bertujuan untuk mengubah design blueprint menjadi bentuk yang dapat dimengerti oleh mesin menggunakan bahasa pemrograman Java dan XML.

4. Verification

Aplikasi yang telah selesai dibangun kemudian akan dilakukan pengujian. Aplikasi diuji menggunakan metode Black Box untuk mengetahui tingkat keberhasilan sistem.

5. Maintenance

Tahap maintenance dilakukan untuk memperbaiki bug atau error pada saat aplikasi digunakan oleh user.

\section{Hasil dan Pembahasan}

\subsection{Perancangan Sistem}

Perancangan sistem pada penelitian kali ini akan menghasilkan beberapa fitur yaitu perhitungan servis berdasarkan jarak tempuh, reminder servis, notepad, dan pusat informasi perawatan spare part sepeda motor. 


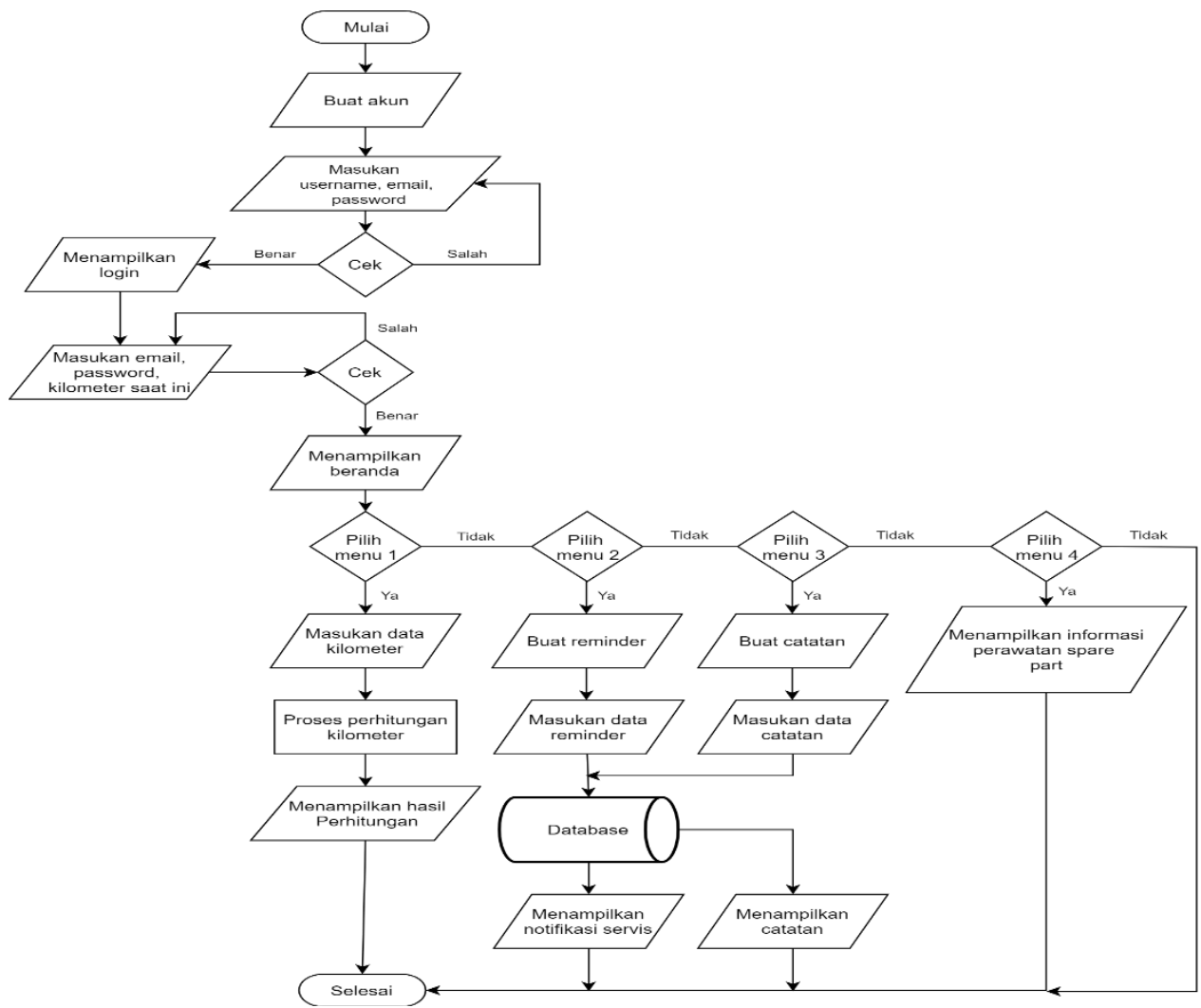

Gambar 2. Flowchart Sistem

Pemodelan dan perancangan sistem digambarkan dengan menggunakan UML (Unifield Modeling Language). Tahap-tahap pemodelan yang digunakan dalam 1. Use Case Diagram Activity Diagram, Sequence Diagram, dan Class Diagram.

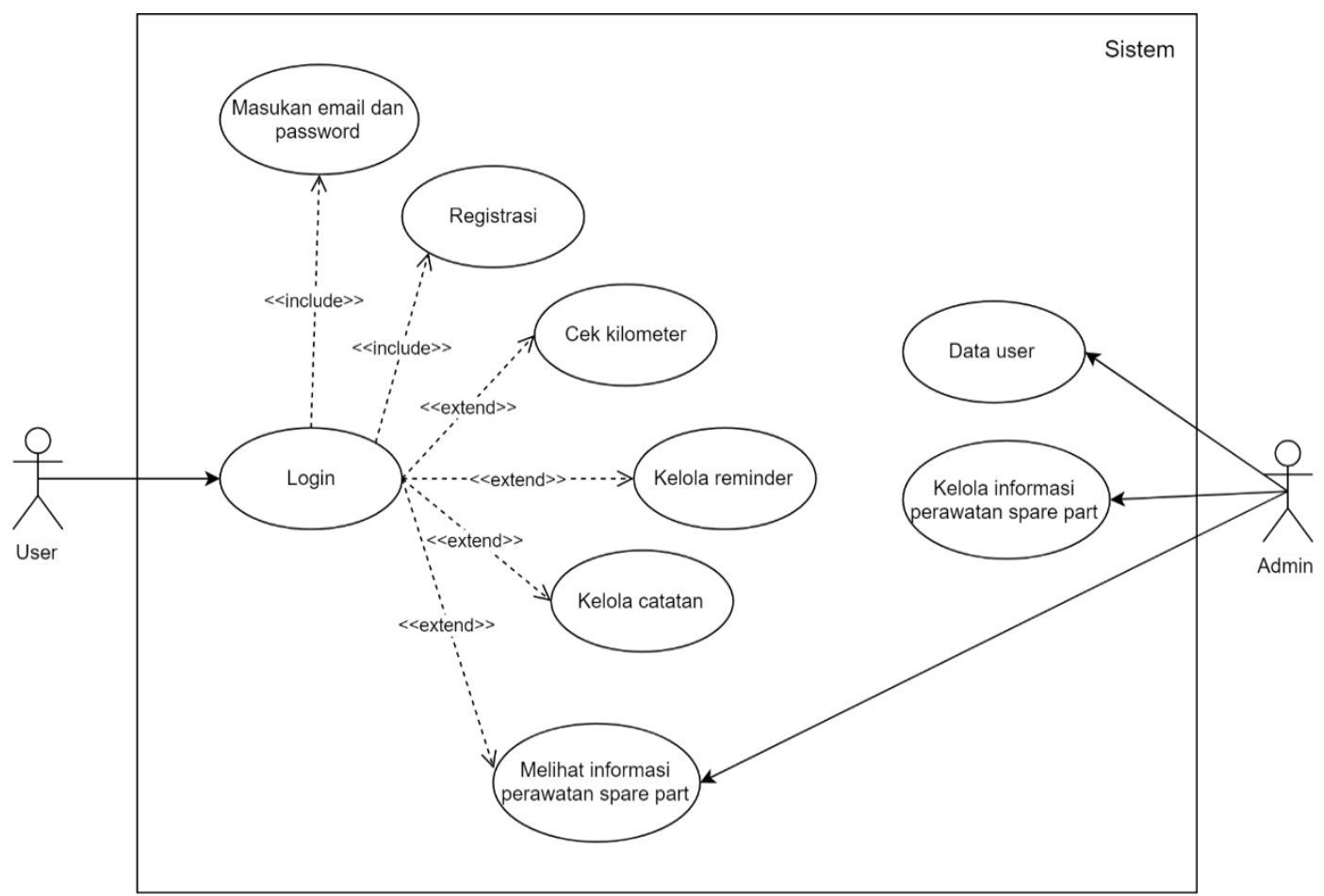

Gambar 3. Use Case Diagram Sistem 
Gambar diatas menjelaskan tentang alur sistem yang terdapat pada aplikasi. Terdapat dua poin penting dalam use case tersebut yaitu actor dan skenario.

\section{Activity Diagram}

Bagian ini menggambarkan dokumentasi alur kerja pada sistem yang bertujuan untuk melihat alur proses sistem.

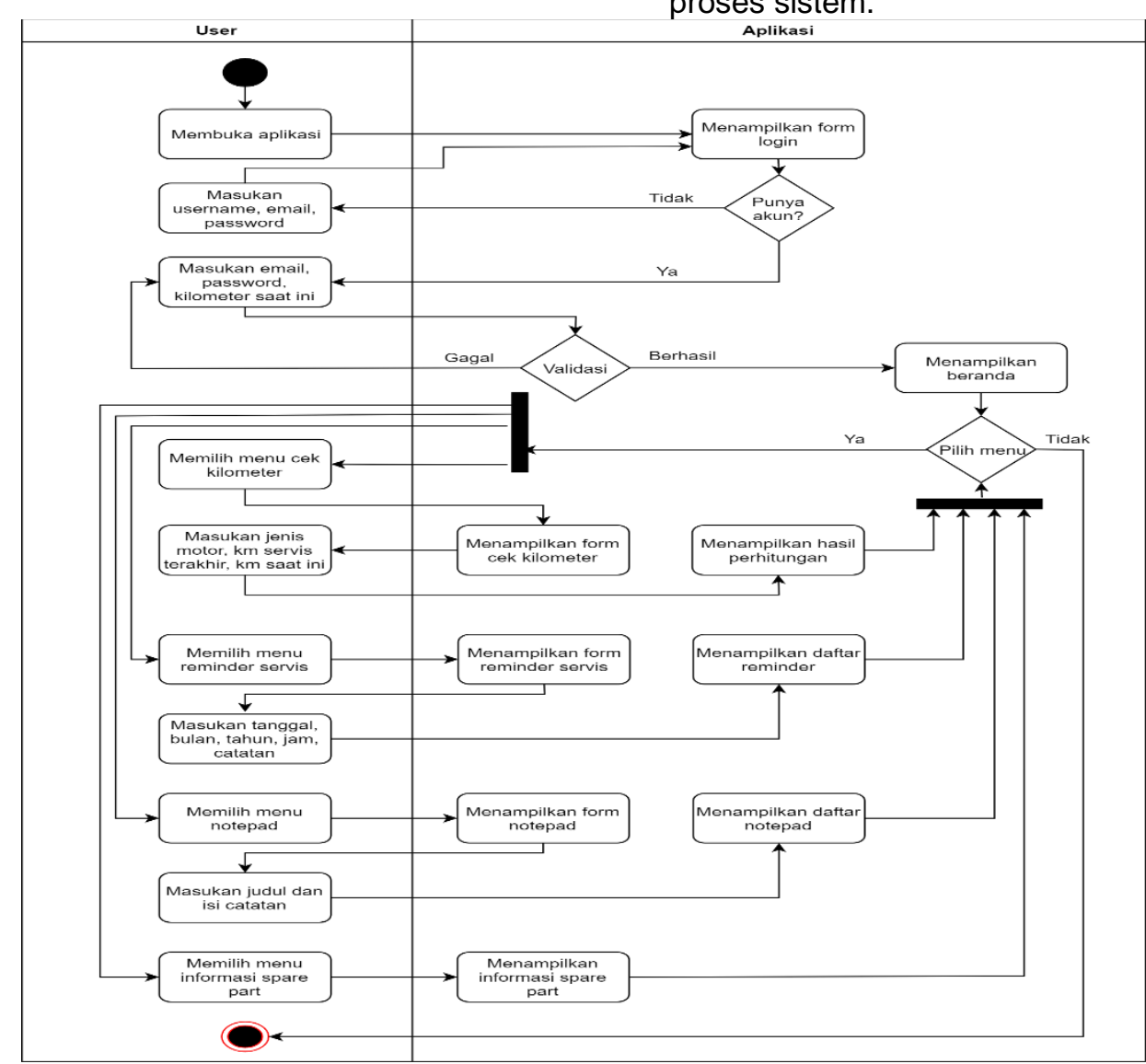

Gambar 4. Activity Diagram Sistem

3. Sequence Diagram

Bagian ini menggambarkan rangkaian pesan yang dikirim antara objek dan interaksi antara objek yang terdapat pada sistem. 


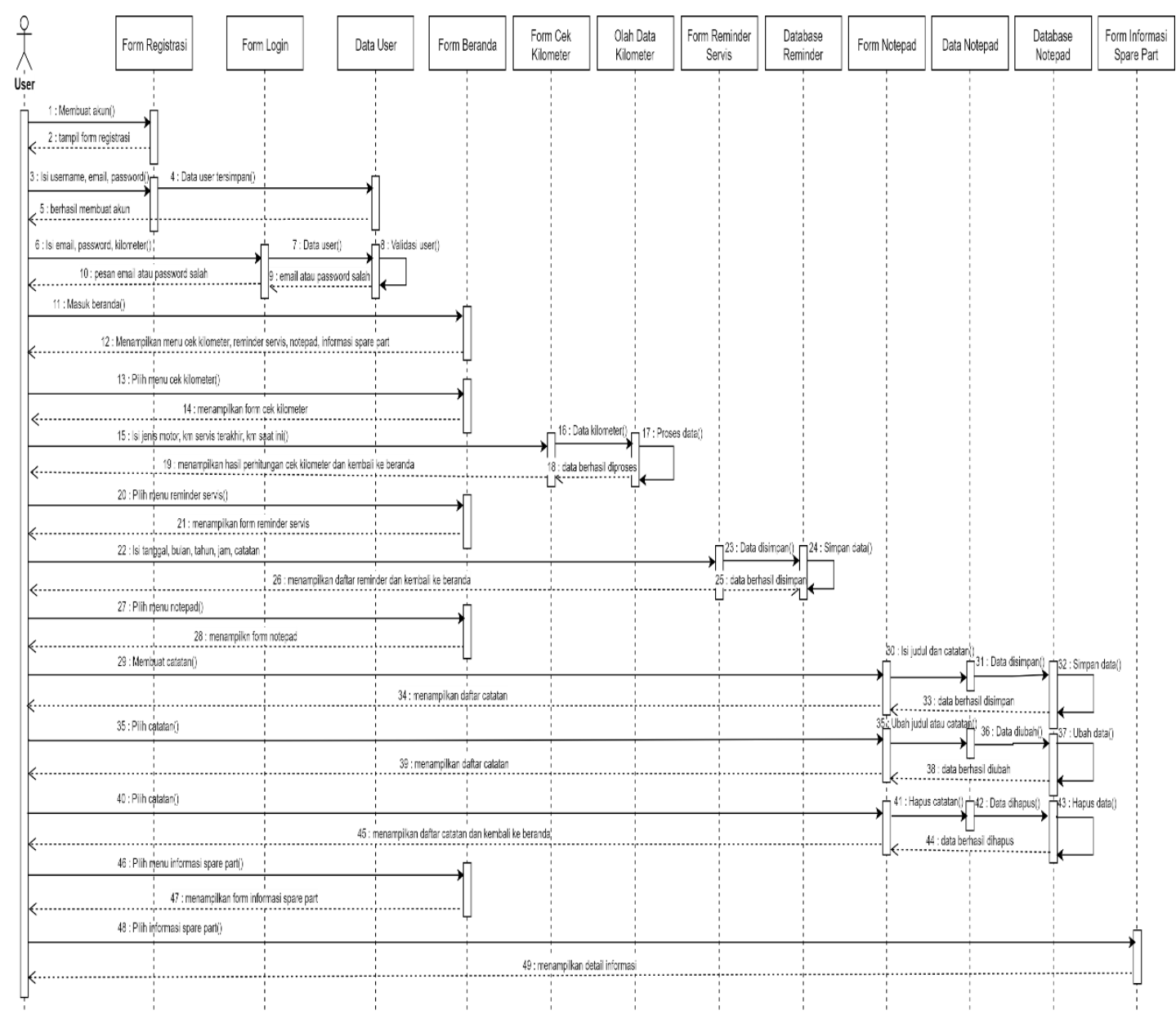

Gambar 5. Sequence Diagram Sistem

4. Class Diagram

Class diagram dibutuhkan dalam

perancangan aplikasi reminder dan

monitoring jadwal servis sepeda motor.

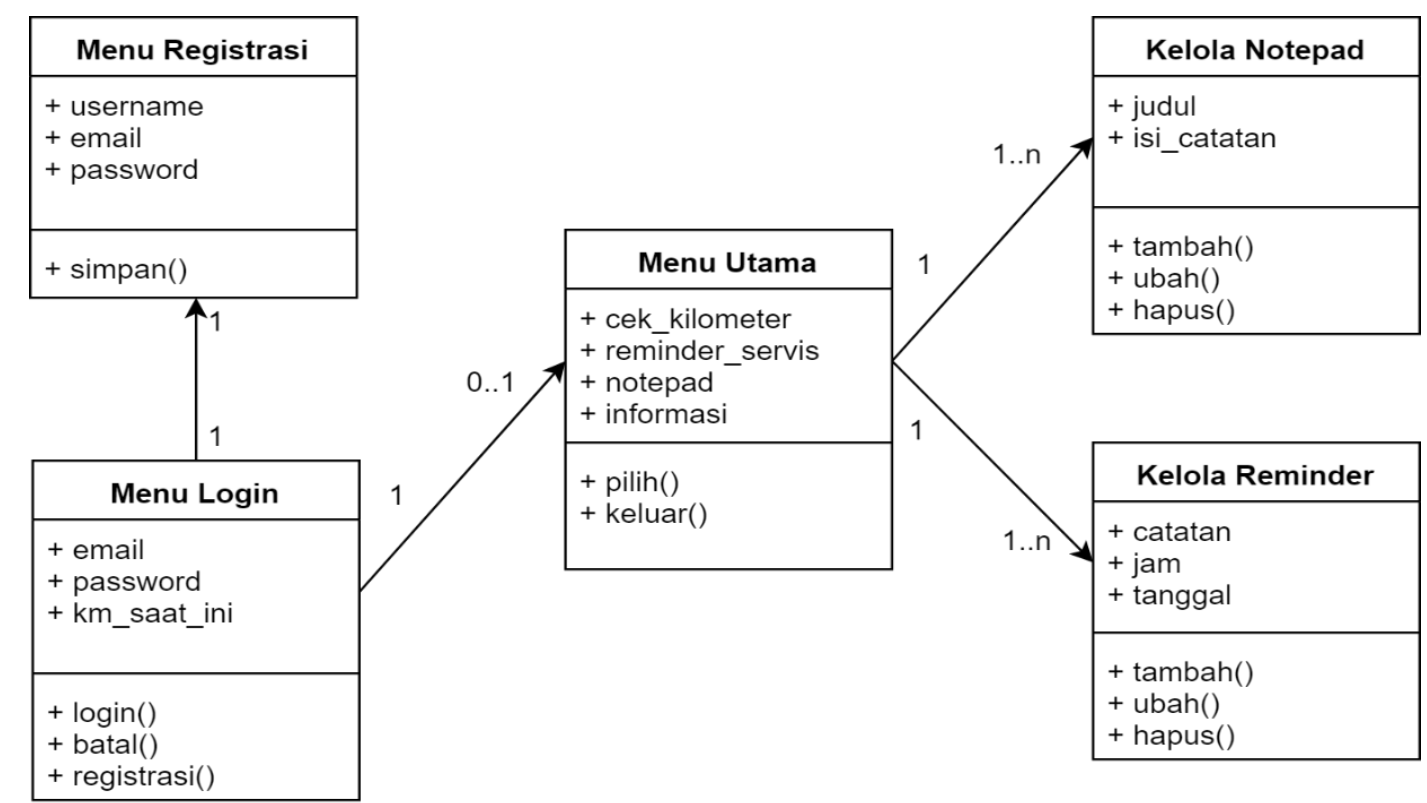

Gambar 6. Class Diagram Sistem 


\subsection{Implementasi User Interface}

User Interface aplikasi reminder dan monitoring jadwal sepeda motor terdiri dari beberapa tampilan yaitu:

1. Tampilan Menu Login

Tampilan menu login berisi masukan email, password, dan kilometer saat ini. Terdapat juga navigasi untuk registrasi akun.

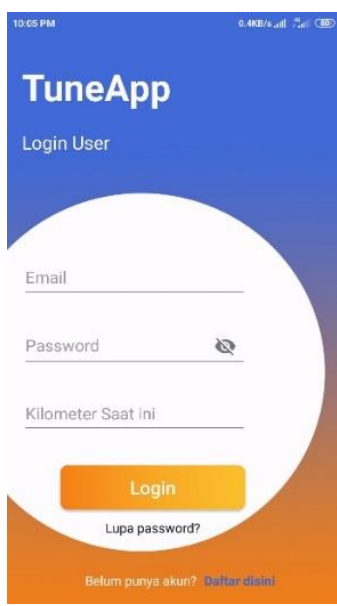

Gambar 7. Tampilan Menu Login

2. Tampilan Menu Registrasi

Tampilan menu registrasi digunakan untuk membuat akun dengan cara mengisi username, email, dan password.

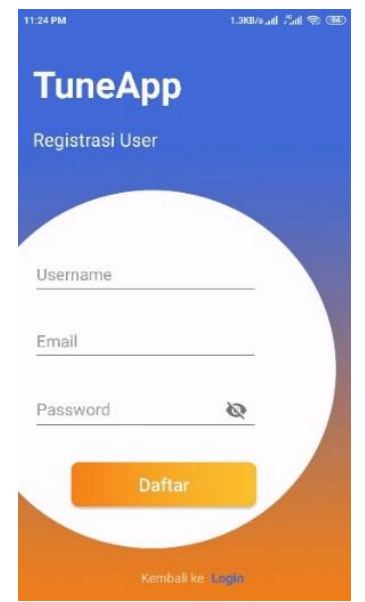

Gambar 8. Tampilan Menu Registrasi

3. Tampilan Menu Beranda

Tampilan menu beranda merupakan tampilan utama berisi menu-menu yang terdapat pada aplikasi dan juga menampilkan daftar count down reminder servis yang telah dibuat.

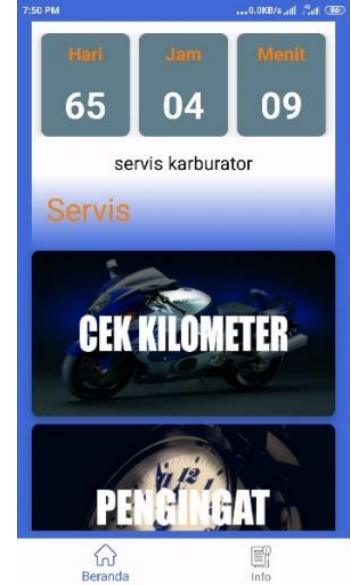

Gambar 9. Tampilan Menu Beranda

4. Tampilan Menu Cek Kilometer Tampilan menu cek kilometer berisi masukan yang dapat digunakan untuk mengetahui apakah sepeda motor harus di servis atau tidak.

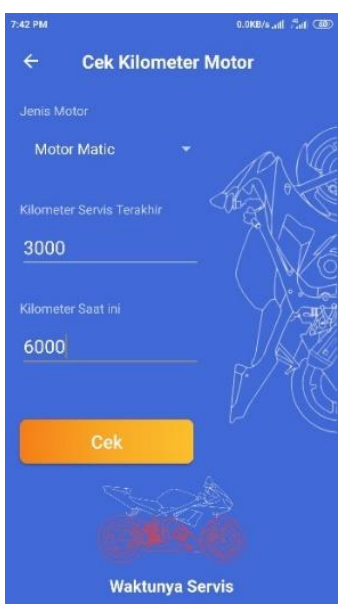

Gambar 10. Tampilan Menu Cek Kilometer (Waktunya Servis)

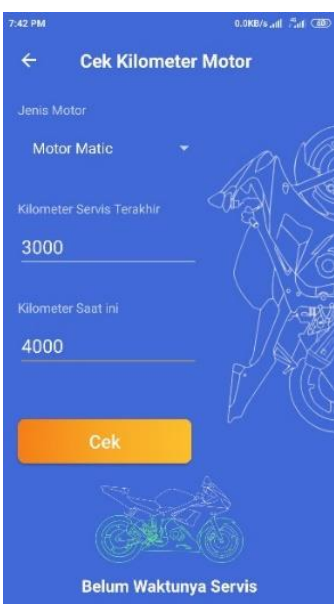

Gambar 11. Tampilan Menu Cek Kilometer (Belum Waktunya Servis) 
5. Tampilan Menu Reminder Servis Tampilan menu reminder servis digunakan untuk membuat dan mengelola reminder servis.

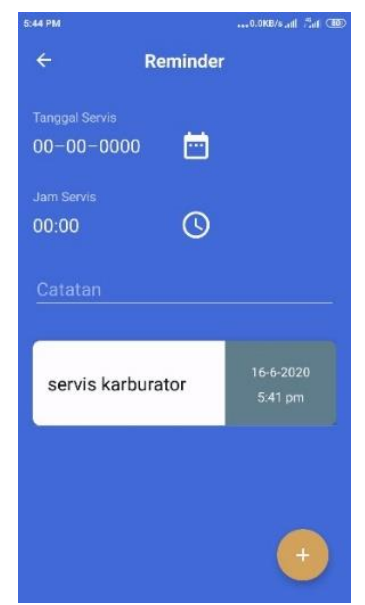

Gambar 12. Tampilan Menu Reminder Servis

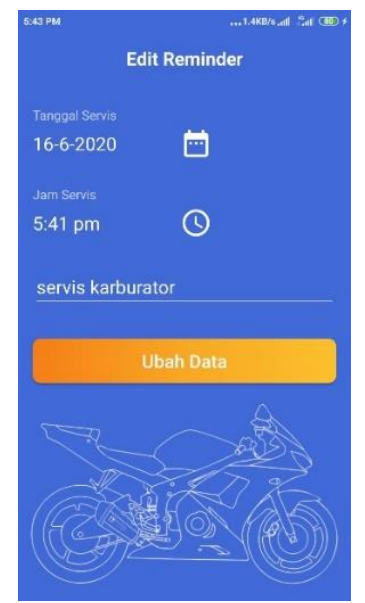

Gambar 13. Tampilan Menu Edit Reminder Servis

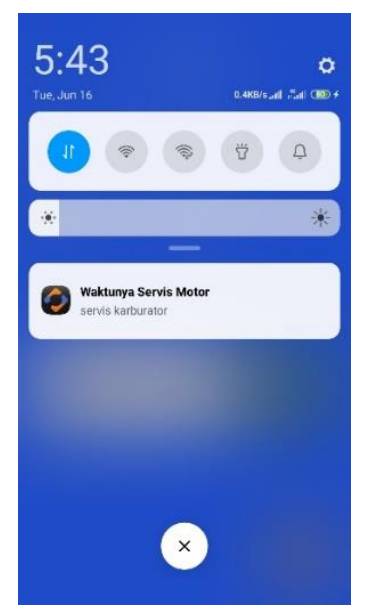

Gambar 14. Tampilan Notifikasi Servis
6. Tampilan Menu Catatan

Tampilan menu catatan digunakan untuk membuat dan mengelola catatan.

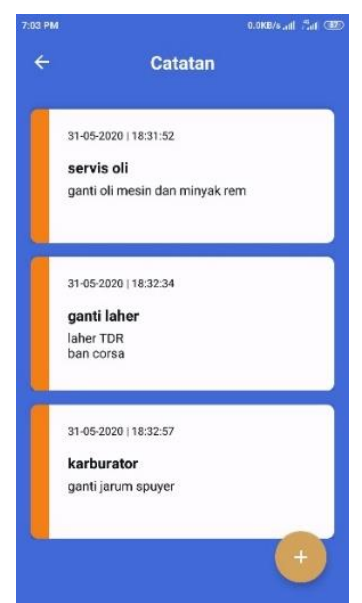

Gambar 15. Tampilan Menu Daftar Catatan

7. Tampilan Menu Informasi Spare Part Tampilan menu informasi spare part berisi informasi perawatan beberapa komponen sepeda motor yang sering mengalami kerusakan.

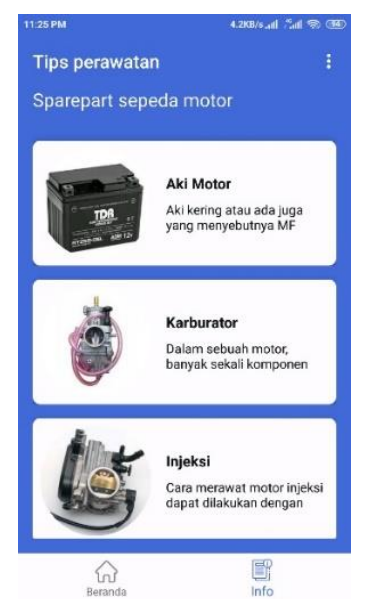

Gambar 16. Tampilan Menu Daftar Spare Part

\subsection{Pengujian Sistem}

Pengujian sistem merupakan bagian yang cukup penting dalam pembuatan aplikasi. Pengujian dilakukan untuk mengetahui kualitas dan kelemahan dari aplikasi. Pengujian aplikasi ini menggunakan metode pengujian Black Box. Pengujian Black Box digunakan untuk menguji semua fungsi-fungsi yang terdapat dalam aplikasi. 


\subsubsection{Rencana Pengujian}

Rencana pengujian dilakukan dengan menguji fungsi-fungsi yang ada di dalam aplikasi, apakah fungsional dari aplikasi berjalan sesuai yang diharapkan atau tidak. Berikut ini merupakan tabel rencana pengujian dari aplikasi yang dibangun.

Tabel 1. Rencana Pengujian

\begin{tabular}{|c|c|c|c|}
\hline No. & Item Uji & Detail Uji & $\begin{array}{c}\text { Jenis } \\
\text { Uji }\end{array}$ \\
\hline 1 & $\begin{array}{l}\text { Splash } \\
\text { Screen }\end{array}$ & $\begin{array}{l}\text { Menampilkan } \\
\text { Splash } \\
\text { Screen }\end{array}$ & $\begin{array}{l}\text { Black } \\
\text { Box }\end{array}$ \\
\hline \multirow{3}{*}{2} & \multirow{3}{*}{$\begin{array}{l}\text { Menu } \\
\text { Login }\end{array}$} & $\begin{array}{l}\text { Menampilkan } \\
\text { Menu Login }\end{array}$ & \multirow{3}{*}{$\begin{array}{l}\text { Black } \\
\text { Box }\end{array}$} \\
\hline & & $\begin{array}{l}\text { Masukan } \\
\text { Email, } \\
\text { Password, } \\
\text { dan kilometer } \\
\text { Saat ini }\end{array}$ & \\
\hline & & $\begin{array}{l}\text { Melakukan } \\
\text { Login User }\end{array}$ & \\
\hline \multirow{4}{*}{3} & \multirow{4}{*}{$\begin{array}{c}\text { Menu } \\
\text { Registrasi }\end{array}$} & $\begin{array}{l}\text { Memilih } \\
\text { Menu } \\
\text { Registrasi }\end{array}$ & \multirow{4}{*}{$\begin{array}{c}\text { Black } \\
\text { Box }\end{array}$} \\
\hline & & $\begin{array}{l}\text { Menampilkan } \\
\text { Form } \\
\text { Registrasi }\end{array}$ & \\
\hline & & $\begin{array}{l}\text { Masukan } \\
\text { Username, } \\
\text { Email, dan } \\
\text { Password }\end{array}$ & \\
\hline & & $\begin{array}{l}\text { Melakukan } \\
\text { Registrasi } \\
\text { User }\end{array}$ & \\
\hline 4 & $\begin{array}{l}\text { Menu } \\
\text { Beranda }\end{array}$ & $\begin{array}{l}\text { Menampilkan } \\
\text { Beranda dan } \\
\text { Count Down } \\
\text { Reminder }\end{array}$ & $\begin{array}{c}\text { Black } \\
\text { Box }\end{array}$ \\
\hline \multirow{3}{*}{5} & \multirow{3}{*}{$\begin{array}{l}\text { Menu Cek } \\
\text { Kilometer }\end{array}$} & $\begin{array}{l}\text { Memilih } \\
\text { Menu Cek } \\
\text { Kilometer } \\
\text { Menampilkan } \\
\text { Form Cek } \\
\text { Kilometer } \\
\end{array}$ & \multirow{3}{*}{$\begin{array}{c}\text { Black } \\
\text { Box }\end{array}$} \\
\hline & & $\begin{array}{l}\text { Masukan } \\
\text { Jenis Motor, } \\
\text { Kilometer } \\
\text { Servis } \\
\text { Terakhir, dan } \\
\text { Kilometer } \\
\text { Saat ini }\end{array}$ & \\
\hline & & $\begin{array}{l}\text { Melakukan } \\
\text { Pengecekan } \\
\text { Kilometer }\end{array}$ & \\
\hline
\end{tabular}

\begin{tabular}{|c|c|c|c|}
\hline & & $\begin{array}{l}\text { Menampilkan } \\
\text { Hasil } \\
\text { Pengecekan }\end{array}$ & \\
\hline \multirow{8}{*}{6} & \multirow{8}{*}{$\begin{array}{c}\text { Menu } \\
\text { Reminder } \\
\text { Servis }\end{array}$} & $\begin{array}{l}\text { Memilih } \\
\text { Menu } \\
\text { Reminder }\end{array}$ & \multirow{8}{*}{$\begin{array}{c}\text { Black } \\
\text { Box }\end{array}$} \\
\hline & & $\begin{array}{l}\text { Menampilkan } \\
\text { Form } \\
\text { Reminder }\end{array}$ & \\
\hline & & $\begin{array}{l}\text { Masukan } \\
\text { Tanggal, } \\
\text { Bulan, } \\
\text { Tahun, Jam, } \\
\text { dan Catatan }\end{array}$ & \\
\hline & & $\begin{array}{l}\text { Melakukan } \\
\text { Simpan Data } \\
\text { Reminder }\end{array}$ & \\
\hline & & $\begin{array}{l}\text { Menampilkan } \\
\text { Daftar } \\
\text { Reminder }\end{array}$ & \\
\hline & & $\begin{array}{l}\text { Menampilkan } \\
\text { Notifikasi } \\
\text { Servis }\end{array}$ & \\
\hline & & $\begin{array}{l}\text { Menampilkan } \\
\text { Form Ubah } \\
\text { Reminder }\end{array}$ & \\
\hline & & $\begin{array}{l}\text { Melakukan } \\
\text { Ubah Data } \\
\text { Reminder }\end{array}$ & \\
\hline \multirow{6}{*}{7} & \multirow{6}{*}{$\begin{array}{l}\text { Menu } \\
\text { Catatan }\end{array}$} & $\begin{array}{l}\text { Memilih } \\
\text { Menu } \\
\text { Catatan }\end{array}$ & \multirow{6}{*}{$\begin{array}{l}\text { Black } \\
\text { Box }\end{array}$} \\
\hline & & $\begin{array}{l}\text { Menampilkan } \\
\text { Form Catatan } \\
\text { dan Daftar } \\
\text { Catatan }\end{array}$ & \\
\hline & & $\begin{array}{l}\text { Masukan } \\
\text { Judul dan Isi } \\
\text { Catatan }\end{array}$ & \\
\hline & & $\begin{array}{l}\text { Melakukan } \\
\text { Simpan Data } \\
\text { Catatan }\end{array}$ & \\
\hline & & $\begin{array}{l}\text { Menampilkan } \\
\text { Form Edit } \\
\text { Catatan }\end{array}$ & \\
\hline & & $\begin{array}{l}\text { Mengelola } \\
\text { Data Catatan }\end{array}$ & \\
\hline \multirow{3}{*}{8} & \multirow{3}{*}{$\begin{array}{l}\text { Menu } \\
\text { Informasi } \\
\text { Spare } \\
\text { Part }\end{array}$} & $\begin{array}{l}\text { Memilih } \\
\text { Menu } \\
\text { Informasi } \\
\text { Spare Part }\end{array}$ & \multirow{3}{*}{$\begin{array}{l}\text { Black } \\
\text { Box }\end{array}$} \\
\hline & & $\begin{array}{l}\text { Menampilkan } \\
\text { Daftar } \\
\text { Informasi } \\
\text { Spare Part }\end{array}$ & \\
\hline & & $\begin{array}{l}\text { Menampilkan } \\
\text { Detail Daftar }\end{array}$ & \\
\hline
\end{tabular}




\begin{tabular}{|l|l|l|l|}
\hline & $\begin{array}{l}\text { Informasi } \\
\text { Spare Part }\end{array}$ & \\
\hline
\end{tabular}

\subsubsection{Hasil Pengujian}

Setelah pengujian dilakukan dengan menggunakan Black Box, maka dapat disimpulkan bahwa sistem bebas dari error. Sistem menunjukkan hasil sesuai dengan yang diharapkan yaitu user dapat membuat reminder servis sepeda motor yang berguna dalam melakukan servis secara rutin. Tidak menutup kemungkinan dapat terjadi error atau kesalahan sistem pada saat aplikasi digunakan. Oleh karena itu perawatan sistem harus dilakukan untuk menghindari hal-hal tersebut.

Berdasarkan hasil dari pengujian dapat disimpulkan bahwa tujuan dari penelitian ini sudah tercapai, yaitu memudahkan para pengguna sepeda motor dalam membuat pengingat servis secara rutin dan mengetahui kapan sebaiknya sepeda motor dapat diservis. Setelah penelitian tercapai diharapkan peneliti dapat meningkatkan pengetahuan dalam membangun aplikasi reminder pada perangkat android.

\section{Kesimpulan}

Berdasarkan hasil perancangan dan pengujian Aplikasi Reminder dan Monitoring Jadwal Servis Sepeda Motor Berbasis Android yang telah dilakukan, dapat disimpulkan hal-hal sebagai berikut:

1. Proses reminder dan monitoring berhasil diterapkan pada sebuah aplikasi berbasis android, dikarenakan pada perangkat smartphone android terdapat fitur notifikasi yang dapat membantu dalam penerapan reminder maupun monitoring. Sehingga sistem tersebut dapat digunakan sebagai sarana untuk membuat pengingat servis menjadi lebih praktis.

2. Dengan adanya aplikasi ini, user dapat membuat pengingat yang berisikan informasi mengenai jadwal servis dengan mudah. User hanya perlu memasukan waktu dan catatan, setelah itu notifikasi akan tampil sesuai dengan waktu yang telah ditentukan. Selain itu notifikasi tersebut dapat menjadi informasi yang dapat digunakan sebagai penjadwalan servis.

3. Aplikasi ini telah disisipkan perhitungan batas maksimal servis berdasarkan kilometer sesuai dengan jenis sepeda motor seperti jenis sport, bebek (cub), dan matic. Sehingga aplikasi ini dapat digunakan oleh user yang memiliki jenis sepeda motor berbeda-beda.

\section{Referensi}

Ayuninghemi, R., \& Abdillah, M. F. (2018). Simulasi Alat Notifikasi Servis Ringan Sepeda Motor Otomatis Berbasis Arduino Nano Terintegrasi Dengan Android. Jurnal Informatika Polinema, 4(3),

168. https://doi.org/10.33795/jip.v4i3.202.

BPS. (2020). Perkembangan Jumlah Kendaraan Bermotor Menurut Jenis, 1949-2018.

https://www.bps.go.id/linkTableDinami s/view/id/1133. (2 April 2020)

Chairin, D. (2018). Alasan Kenapa Motor Banyak Digemari Masyarakat Indonesia.

https://www.tribunnews.com/otomotif/ 2018/12/10/alasan-kenapa-motorbanyak-digemari-masyarakatindonesia. (4 April 2020)

Faisal, M. (2019). Rancang Bangun Sistem Informasi Akademik Berbasis Web Dengan Metode Waterfall. Seminar Nasional Inovasi Dan Tren (SNIT), 1(Juni 2019), A-134-A-139. http://seminar.bsi.ac.id/snit/index.php/ snit-2018/article/view/54.

Korlantas. (2020). STATISTIK LAKA. http://korlantas.polri.go.id/artikel/korla ntas/113?Statistik_Laka. (16 April 2020)

Novi Airbat Lestiono, P., Informatika, T., Informasi, F. T., Kristen, U., \& Wacana, S. (2016). Perancangan dan Implementasi Aplikasi Pendaftaran dan Sosialisasi UMKM Berbasis Android ( Studi Kasus: Disperindagkop Salatiga ) Artikel IImiah Program Studi Teknik Informatika Fakultas Teknologi Informasi Universitas Kristen Satya Wacana Salatiga April. April.

Rohman, A. (2017). Belajar dari Kasus Motor Terbakar, Ini Alasan Mengapa Motor Harus Diservis. https://www.carmudi.co.id/journal/belaj ar-dari-kasus-motor-terbakar-inialasan-mengapa-motor-harusdiservis/. (5 April 2020)

Santana, R. A., Risqiwati, D., \& Sari, Z. 
(2017). Rancang Bangun Sistem Informasi Servis Oli Sepeda Motor Menggunakan Odometer Berbasis LBS. Kinetik, 2(1), 17. https://doi.org/10.22219/kinetik.v2i1.9

8. 